\title{
Review
}

\section{Changing referents: Learning across space and time in China and the west}

\author{
Leigh Jenco \\ Oxford University Press, New York, 2015, 296pp., ISBN: 9780190263812
}

Contemporary Political Theory (2017) 16, 588-591. doi:10.1057/s41296-017-0092-4; advance online publication 22 February 2017

Leigh Jenco's Changing Referents uses its subject, a series of Chinese debates about reforms in the late Qing, to construct an intricate argument about the nature and methods of comparative political theory (CPT). The Chinese reformers are a good analogue, Jenco notes, for just as contemporary CPT is a response to the provincialism and parochialism of which political theory, focused on a North Atlantic canon, has been accused, so too did the Chinese reformers struggle with the painful realization that their "presumably universal values [were] in fact particular" (p. 4). The reformers' proposals have typically been classed as a variant of the modernization thesis. However, Jenco argues that their justifications and proposals for learning from the "West" provide substantive and methodological resources for CPT's self-assigned task of cross-cultural learning. [I use "the West" according to Dallmayr's suggestion: as a nominal and convenient but utterly inadequate placeholder (Dallmayr 1997)]. In Jenco's hands, the Chinese reformers become guides for the contemporary CPT project - the Chinese insights can be used, in Jenco's terms, to "discipline" political theory. Hence, on a reflexive and methodological level, Jenco's book itself is an exemplar of how an author has allowed herself to be "disciplined" by "non-Western" sources.

Thus, Changing Referents is a demonstration of what Jenco contends is the real work of CPT, namely to learn from "others," rather than about them. CPT should show how non-Western sources can furnish current practices of political theorizing (in the North Atlantic academy) with intellectual, conceptual, and critical resources for the present, much in the same way that thinkers such as Plato or Hobbes are still presumed to "speak" to "us."

This review will not assess the historical accuracy of Jenco's work, but focus on its implications for political theory. Since Jenco makes her case through an interpretation of the Chinese debates, I provide a brief summary of the debates before returning to the stakes of her project, as outlined in her first two chapters.

Before proceeding, we should note the polysemy of the descriptor, "Chinese." The Chinese reformers employ what has been called a "culturalist" understanding

(C) 2017 Macmillan Publishers Ltd. 1470-8914 Contemporary Political Theory Vol. 16, 4, 588-591 www.palgrave.com/journals 
of what it means to be "Chinese," based on wen [文] (roughly translatable as "culture"). Wen is cultivated by a Confucian education, and maintained by rituals and norms. In contrast to a later ethnically based nationalism, this culturalist definition of "Chinese," which originated in the Qin-Han era, allowed the assimilation of non-ethnic Han conquerors and elites.

Let us begin with the quixotic thesis of "Chinese Origins for Western Knowledge" (Xi xue zhong yuan [西學中源]), recounted in Chapter 3. Its defenders claim that prototypes of "Western" modes of knowledge such as science and mathematics already existed in the classical Chinese canon. These claims are typically seen as a compensatory consolation for a series of Chinese military defeats at the hands of "Western" powers; more productively, they legitimized the introduction of scientific and technological subjects within an educational system based on classical, neo-Confucian ("ru" [儒]) learning. However, Jenco argues that the thesis also illuminates a crucial dimension of learning from an "Other." If "Western" knowledge can shed its "foreign" status to become "Chinese," then it becomes an integral part of a "Chinese" worldview. (Here it helps to bear in mind the "culturalist" definition of "Chinese.") As such, it has the potential to alter what can be recognized as knowledge, of what counts as worth knowing. For Jenco, this is instructive for contemporary attempts to unsettle the canon: we must not simply add more and more "culturally other" slots to political theory, but to recalibrate what is admissible as theorizing, to transform the very practice of political theory altogether.

Chapters 4 to 6 examine the education reforms proposed by thinkers of the Reform Movement of 1898 (wuxu bianfa [戊戌變法]), which Jenco refers to by the pinyin Romanization, bianfa [變法], for reasons that will become clear shortly. In 1895, China suffered a humiliating defeat by Japan, a former tributary state. Chinese bianfa thinkers argued that the Western military hardware in China's possession was inadequate without the Western knowledge that made the very idea of such technÕ possible in the first place (what one could call an epistemological spirit, perhaps). They advocated a total overhaul of Chinese modes of knowledge acquisition and production, and in particular, the demolition of the $r u$ or neoConfucian civil examination system, the decisive arbiter of an entire system of governance. Reformers such as Tan Sitong argued that knowledge is embodied in a panoply of practices - material, institutional, practical. Meiji modernization had secured these conditions for Japan, and consequently its victory over China. This is what Jenco wishes us to learn from bianfa thinkers: that differences across intellectual traditions are underwritten by a slew of material, institutional, and collective differences. This is why reformers called their prescriptions bianfa: bian [變] means "change," and $f a$ [法] refers to laws, institutions, and "the wider normative patterns that enable their functioning" (p. 111), or, the "referents" of knowledge. The bianfa thinkers, Jenco argues, teach us that an epistemic shift 
cannot be accomplished without concomitant changes to the social and institutional contexts of knowledge production.

Chapters 7 and 8 bring us into the May Fourth Era, inaugurated by student protests in Tiananmen Square on May 4, 1919, against the terms laid out for China in the Versailles Treaty. The May Fourth thinkers sought to show how rapprochement or synthesis was possible between two culturally distinctive systems. They embraced a dynamic conception of history: since one only approaches the "past" through a perspective of the present, history is never a static "repository of values" (p. 185); it always also bears an interpretation of the present. In relation to this mobile "past," a cultural "Other" appears as a modality of the unprecedented: i.e., the "West" is not so much a geopolitical entity as it is a (new) way of life. For Jenco, the May Fourth thinkers articulate a diachronic and dynamic vision, in which "China" and the "West" are not two intractable civilizational blocs confronting each other across an abyss, but ways of life that have to be enacted; the "present" becomes an aleatory potentiality, the site of human agency.

The concluding chapter spells out what we have to do for CPT in the present. Jenco's suggestions turn upon her argument that cross-cultural theorizing requires not just an epistemological sea change for the individual scholar, but a collective and institutional "re-centering." Jenco argues that in order to learn from others, we have to question and perhaps replace the "evidentiary rules" of the discipline, to redraw "the very criteria that would signify knowledge and govern its processes of acquisition" (p. 148). This in turn entails changing the institutional frameworks underpinning knowledge production.

I begin with a relatively minor point. Some of the ideas characterized as "Chinese" already bear the marks of "Western" scholarship. For instance, the reformer Yan $\mathrm{Fu}$, as Jenco notes, drew from the ideas of Herbert Spencer and Thomas Huxley; strands of the May Fourth movement drew explicitly on the ideas of Karl Marx; the idea of a stagnant East is one of the most common caricatures of the "sick man of Asia." In other words, the methods proposed by the Chinese thinkers for incorporating a "Western learning" themselves already bear traces of this "Western learning." The "learning" that Jenco recounts has already partly taken place "behind the scenes" as it were. This niggling detail leads us to certain challenges facing CPT as a whole.

First, let's be clear that the point is not to look for some purely "Chinese" (or Indian, Islamic, etc.) method or content. This would be a naïve and impossible quest, given the long histories of influences from "external" sources (such as Buddhism), the fractured history of China and "Chineseness" itself, and the elasticity of the description and definition of "Chinese." The issue bedeviling CPT is the fact that the markers now used to denote "cultures" and "traditions" are themselves contingent, anachronistic, sometimes nativist, even as "cultures" tend to be protean and porous (overdrawn distinctions tend to be an institutional habit). There is a sense in which, like all the most compelling forms of learning, we will 
not know just what we may find in CPT until we get there. Hence, though we begin with these crude markers, Jenco shows us some ways of working past them.

CPT may not always be capable of bearing the ethical burdens we place upon it. Comparative theorists often invoke postcolonial critiques as a motive for CPT (Vacano, 2015). Jenco, too, frames the project of cross-cultural learning in terms of giving voice to subalternity, which she defines as "the inability of a voice or discourse to permeate the communities whose discourses take it as objects of knowledge" (p. 93). Yet, as Loubna El Amine (2016) notes, there is an important sense in which the Western "others" are not subaltern; "Western learning" could be seen as a hegemonic effect. The Chinese reformers' observations on cross-cultural learning need not be rendered invalid by this point. However, it also raises the related question of oppressions and marginalizations internal to a tradition broadly conceived. Jenco's recent work in fact has examined how Chinese culturalism was mobilized for Chinese imperial policy (Jenco, 2016). Here is where CPT must work as a collective enterprise: as the field becomes further refined, we will, hopefully, see increasingly fine-grained analyses of dynamics internal to, and across, "nonWestern" traditions.

"Post-truth" was declared word of the year by Oxford English Dictionary for 2016. In these times of "post-truth" politics, the multiplicity - of methods, of concerns - of CPT may appear a descent into Babel from the shared ethico-political language promised by the canon. Jenco demonstrates how CPT may also show us other ways of reaching the truth, as well as the possibility of other truths; we can work to make it a promise, not a threat.

\section{References}

Dallmayr, F. (1997) Towards a comparative political theory. The Review of Politics 59(3): 421-428.

El Amine, L. (2016) Review of changing referents: Learning across space and time in China and the west, by Leigh Jenco. Perspectives on Politics 14(4): 1200-1202.

Jenco, L. (2016) Secularism beyond christian political theology: Thinking from Taiwan and China. Philadelphia, PA: Presentation at the American Political Science Annual Meeting.

Von Vacano, D. (2015) The scope of comparative political theory. Annual Review of Political Science 18: $465-480$.

Dorothy H. B. Kwek

Universität Konstanz, 78457 Constance, Germany

dorothy.kwek@uni.kn 